ANKARA TIP MECMUASI (THE JOURINAL OF THE FACULTY OF MEDICINE) Vol. $47: 331-346,1994$

\title{
PANKREAS ORGAN TRANSPLANTASYONU
}

\author{
İsmail Haluk Gökçora*
}

İnsulin'e bağımlı «tip I diabetes mellitus» pankreas'ın endokrin Langerhans adacıklarının genetik veya çevrel etmeniere bağlı olarak otoimmün hasarından oluşur. Genelde toplumun \% 5'ini ilgilendirir. Yetişkin yaşlarda en önemli böbrok yetmezliği ve körlük, ekstremite amputasyonu ve impotans nedenidir. Ayrica atheroskleroz'un hizla ilerlemesine, anormal lipid metabolizmasına ve kardiyovasküler bozunlara yol açmaktadır. Sağıltımindaki tüm gelişmelere karşın birçok hastanın mikroanjiopatili sekonder komplikasyonlara kadar ilerlediği görülmektedir. Tip I diyabetikler normal toplumla kıyaslandığında; retinopati ve körlüğe 25 , böbrek yetmezliğine 17 , ekstremite gangrenine 5, kalb hastalıklarına 2 kez daha çok oranda tutulmaktadırlar. Sürekli insulin kullanmak «biofeed-back» mekanizmalardan yoksun sıkıntılı ve kötü bir yaşam tarzına neden olmaktadır. Pankreas aktarımından amaç, kişide normal glisemiyi oluşturmak, sekonder komplikasyonlardan korumak veya geciktirmek için yeterli ve otokontrollu bir insulin kaynağını sağlamaktır. Bir yandan kanciaki glukoz düzeyini monitorize ederken; kapalı devre halinde kana insulin pompalayabilen yapay cihazlar veya adacık hücre nakilleri henüz başarıya ulaşamamıştır. Güncel koşullarda en uygun endokrin replasman yolunun damar yapısıyla birlikte pankreas aktarımı olabileceği görüșü, artan oranda kabul görmektedir $(2,9,15,16)$.

İlerleyici ve zararlı komplikasyonların hangi diyabetiklerde ortaya çıkacağının bilinmesi ve organ aktarımıyla birlikte gelecek cerrahi ve tıbbi risklerle, yaşam boyu sürecek immünosupresyonlu bir hastada sağlayacağı yararlar arasındaki dengenin belirlenmesi pankreas solid organ aktarımma karar vermede esastir.

Pankreas transplantasyonu sonrası glisemi normale ulaştığında ekzojen insulin kesilebilmesi başarıyı gösterir. İntravenöz glukoz tolerans testinde olguların ancak yarısının normal olmasinı

\footnotetext{
* A. Ü. Tıp Fakültesi, Çocuk Cerrahisi Anabilim Dalı, Ögrretim Üyesi Geliş Tarihi : 25 Ocak $1994 \quad$ Kabul Tarihi : 2 Mart 1994
} 
çoğu araştırıcı birlikte kullanılan immünosupressiv ilaçlara bağlamaktadırlar. Pankreas aktarımı kalb ve karaciğer gibi alternatifi olmayan hayat kurtarıcı bir girişim olmayıp; daha kaliteli bir yaşam sağlamak için ve diabetin sekonder komplikasyonlarının önlenmesinde etkin bir yöntem olarak kabul edilmektedir $(6,11,13,14)$.

Tarihçe : 1891'äe Williams, koyun pankreas ekstresini diyabetik komadaki hastanın karın duvarı içine yerleştirerek, insulin'in bile keşfinden önce, ilk kez pankreas dokusu aktarımını gerçekleştirmiştir. 1922'de Best ve Banting'in ayrı ayrı «insulin»i bulmalarından sonra pankreas dokusu aktarımı için gösterilen ilgi yitirilmiştir. 1966'da Kelly ve Lillehei ilk kez insandan insana, pankreas kanalının bağlanmasıyla yapilan, pankreas segmenter organ (corpus ve cauda) ve birlikte böbrek naklini g'erçekleștirmișierdir. 1972'de izole Langerhans adacık hücrelerinin serbest greft halinde kullanmalarıyla solid organ transplantesyonuna olan ilgi yine aza!mıştır. Ancak insan pankreas dokusundan aktarıma yeterli sayılacak miktarda adacık hücresi izole edebilmek henüz pratik bir aşamaya ulaşamadığından ve bu etkin adacık sayısına ulaşabilmek için en az 2 - 4 donörden hücre gruplarının biraraya getirilmesi sorunu bulunduğundan ve de oluşan rejeksiyonun solid organınkinden farksız olması nedeniyle, pankreas Langerhans adacık hücreleri naklinde henüz beklenen atılım sağlanamamıştır. 1973'de Gliedman ve ark. pankreas organ aktarımında ekzokrin salg1yı lümenli bir organa (üreter'e) drenajını önermişler, 1974'de Groth ve ark. segmental pankreas aktarıminı alıcinın Roux-en-y ince barsağına akaçlamışlardır. 1978'de Dubernard pankreas kanalı içine sentetik polimer enjekte ederek ekzokrin sekresyonu engellerlerken, Minesota grubu drenajı periton içine yapmışlardır. 1982'de Sollinger ve daha sonra Nghiem'in modifiye ettiği teknikle pankreas ekzokrin salgısını duodenum aracılığıyla mesaneye akaçlanmıştır (sit. 2,6,9,13) .

1960 ve 70'li yıllarda yapılmış olan pankreas aktarımları yılda 10'un altındayken, cerrahi teknik ve immunosupresyonda sağlanan yeniliklerle; "Cyclosporine-A» (CsA) ve FK506, özellikle böbreḱle birlikte pankreas aktarımı uygulanan hastaların sayısının da artmasiyla, yılda 400 500'e kadar çıkmıştır. 1994'e kadar insanlarda yapılan pankreas aktarımılarının sayısı 4500'ü geçmiștir. Genelde kadavra vericiler kullanılmış ve en çok diyabetli ve son evre böbrek hastalığı bulunanlara ikili organ aktarımı uygulanılmıştır. Ancak 1986'dan bu yana gittikçe artan oranda ( $\%$ 25) preüremik hastalara tek bașina pankreas organ aktarımları yapılmaktadır. En deneyimli ünitelerde bir yıllık greft survi oranı tek başına pankreas aktarımında \% 50'ye; böbrekle birlikte yapılan aktarımında ise \% 90'a ulaşmıștır $(6,9,11,13,14,15,16)$. 


\section{"Cluster» (Grup) Organ Transplantasyonu}

Birlikte yapılan solid organ pankreas-böbrek aktarımlarından sonra transplantasyon yapılmıș böbrekte diyabetik nefropatinin gelişmediği ve nöropatilerin düzeldiği, buna karşılık tek başına böbrek aktarımı yapılan diyabetiklerde nefropatinin 2 yıl gibi çok kısa bir süreçte gerçekleşebileceği saptanmıştır. Bugüne değin uygulanan pankreas-böbrek transplantasyonları tüm pankreas solid organ aktarımlarının \% 80'ini oluşturmaktadır. Pankreas aktarımı diyabetin başlangı̨ evresinde uygulanırsa, komplikasyonların oluşmasını engellediği veya en azından hastalığı stabilize ettiği söz konusu olduğundan, pankreas'ın yanısıra böbrek aktarımına da gerek yoktur. Glomerüler filtrasyon hızının erişkinde 40-60 ml/dakika'dan düşük olduğu koşullarda ise pankreas transplantasyonunun yanısıra böbrek de aktarılmalıdır (16).

1980 yılında International Pancreas Transplant Registry (IPTR) ismiyle uluslararası pankreas aktarımı kayıt dizgesi oluşturulmuştur. Son yıllarda başarının artmasında; yeni teknoloji, daha iyi HLA kroslanması, pankreas prezervasyosyonunun 30 saatin altinda olmasi, pankreas-böbrek birlikte aktarımı, alıcı yaşının 45 yaşın altında olmasl, dörtlü immünosupressiv uygulama olumlu rol oynamıştır (14).

\section{Pankreas Aktarımı Endikasyonları}

1. Son evre nefropati $(40 \mathrm{ml} /$ dakika altında kreatinin klirensi; birlikte böbrek aktarımını da gerektirir)

2. Beklenen diyabetik nefropati (proteinüri)

3. Önemli diyabet sağıltım sonuçları

3. 1. Hiperlabil diyabet

3. 2. Hipogliseminin farkında olmamak

3. 3. Hipoglisemiye karşı endokrin yanıtta bozukluk

3. 4. Derialtına verilen insulin'e direnç veya duyarsızlık

4. Total pankreatektomi sonrası endokrin ve ekzokrin yetmezlik

Diyabetli hastada proteinüri varsa, ortalama 7 yıl içinde son evre böbrek yetmezliğine gidiş görülmekte ve normal toplumla kıyaslandığında $100 \mathrm{kez}$ daha fazla mortalite olmaktadır. Proteinüri'siz bu tür hastalarda ise oran ancak 2 mislidir. Bu nedenlerle nefropatinin gelișeceğini belgeleyen proteinüri'li (erken) olgular tek başına pankreas organ aktarımı için endikasyon oluștururlar. 
Kronik pankreatit gibi nedenlerle total pankreatektomi yapılmış olanlarda, aşırı labil diyabetlilerde, hipoglisemi ataklarının farkedilmediği ve bunlara endokrin yanıtı olmayan kişilerde, insuline karşı direnç kazanmışlarda da son yıllarda pankreas transplantasyonları uygulanmaktadir.

Alıcı şahsın ameliyat, immünosupresyon ve oluşabilecek komplikasyonlar yönünden bilinçlendirilmiş olması ve bu yönde psikolojik olarak uyumlulugu şarttır. Diyabeti yüzünden gelişebilecek komplikasyonların önüne geçileceği ve yaşam kalitesinin çok daha iyi olacağı yönünde bilgilendirilmelidir $(14,16)$.

Pankreas Aktarımı Kontrendikasyonları

1. 60 yaş üzeri

2. Malignite

3. Psikoz

4. Aktif enfeksiyon

5. Önemli diyabet komplikasyonları

5. 1. Sürmekte olan ekstremite diyabetik gangreni ve körlük

5. 2. İlerlemiş ve anjinası bulunan koroner kalb hastalığı

5. 3. Sağıltıma yanıt vermeyen kalb yetmezliği

5. 4. İlerlemiş çevrel nöropati

6. Aşırı şişmanlık (idea! ağırlığının \% 50'sinden fazla ağırlıkta olmak)

7. Aktif sigara içilmesi

8. Aktif ilaç bağımlılığı

Sağıltılamayan kötümcül urlar ve psikoz herhangi bir solid organın aktarımı için kontrendikasyondur. Başta enfeksiyonlar olmak üzere herhangi bir akut hastalık aktarım öncesi tamamen iyileştirilmelidir. Sürmekte olan ekstremite gangreni, önemli koroner kalb hastalığı, düzeltilemeyen kalb yetmezliği veya hastayı yatağa bağlayan lerlemiş çevrel nöropati gibi diyabet komplikasyonlari da bizzat pankreas organ transplantasyonuna kontrendikasyon teşkil ederler (11).

\section{Alıcı Hastanın Değerlendirilmesi}

Koroner hastalığın yüksek sıklığı nedeniyle efor elektrokardiyogramının çekilmesi ve Thallium-201 myokardial sintigrafisi çok yararlıdır. Belirgin bir stenoz söz konusuysa koroner köprüleme veya anjioplasti işlemi organ aktarımınından önce tamamlanmalıdır. Önemli perife- 
rik arteriopati'lerde anjiografi ve köprüleme-anastomoz işlemi yapılmalıdır. Mide hareketi ve "candida» kapsamı araştırılmalı, mesane'nin makroskopik olarak görüntülenmesi ve endoskopisi ve fonksiyonel olarak izlenmesi gereklidir. Pre-üromik nefropatiliierde glomerüler filtrasyon hızı ve histopatolojisi zaman aralıklarıla değerlendirilmelidir. Nörolojik ve göz gibi muayeneleri yapılmalıdır.

Alıcı seçiminde ABO kan grubu uyumu, sensitizasyon derecesi, HLA antijen uyumu, alıcı listesinde bekleme süresi, tıbbi ivedilik ve negatif T-lenfositotoksik kros-meç gibi koşullar rol oynar.

Verici Seçimi : Diyabetli, akut, k“onik veya travmatik pankreatit'i, malignite ve septik bulguları olmayan, alkolizmi veya ilaç bağımlılığı, HIV virusu bulunmayan, 60 yaşına kadar her şahıs donör kabul edilebilir. Ancak en büyük sıkıntı donör olarak uygun hastaların bulunmasindaki zorluktur. Günümüzde; kalb, karaciğer ve ince-barsak allogreft aktarımlarında olduğu gibi HLA uyumluluğı dikkate alımaksızın ABO kan grupları uygunluğu önemsenmektedir. HLA uyumluluğu dikkate alindığında rejeksiyon daha az oranda olmaktadir. Beyin ölümü gerçekleşmiş verici hastalarda sürekli glukozlu infüzyonlar, beyin damarlarındaki tıkanıklık; kən glvkoz ve amilaz düzeyini yükseltebileceğinden vericiye bir saat süreyle glukoz'suz serum verildiğinde ancak normal değerin iki mislinden daha yüksek bir düzeyde devam ederse pankreas alınmamalıdır. Hemoglobin $A_{1}$ varlığının araștırılması bir başka pankreas endokrin işlevi saptama yöntemidir. Serum amilazı normalin 3 mislinden fazla yüksekse pankreas kullanılmamalıdır. En iyi değerlendirme; verici ameliyatı sırasında pankreas dokusunun sarimsı, yumuşak ve homojen yapisinin saptanmasiyladir. Pankreas dokusunda skleroz, kalsifikasyon veya önemli renk değișikliği söz konusuysa, kullanılmamalıdır. $30 \mathrm{Kg}$ beden əğırlığı altındaki vericilerin damar çaplarının küçüklüğü ve 60 yaşın üzerindekiierde atheroskleroz nedeniyle, aktarım sonrası vasküler tromboz oranı artı̆ı̆ı unutulmamalidır $(1,14)$.

Donörün yoğun bakımı sırasında hemodinamik stabilite, organ perfüzyonu ve oksijenizasyon yönünden agresiv bir tutumlu solunum desteği, yeterli sıvı giriş ve çıkış kateterizasyonu monitorizasyonuna dikkat edilmelidir. Düşük doz dopamin ile kan basıncının 90 mmHg'nın üzerinde tutulması ve diürezi sağlanmasına, intravenöz bol kolloid verilerek pankreas ödemini en aza indirgenmesine çaìışlır. 
Canlı akrabadan alınan segmenter pankreas greftlerinde temel neden, kadavra organ teminindeki yetersizlik ve doku reddinin daha az olmasıdır. Uygun akraba seçiminde alıcı diyabetinin başlangıç yaşından en az 10 yaş daha fazla yaşlı olması, oral ve intravenöz tolerans testlerine normal insulin yanitı verebilmeleri kriter olarak kabul edilir $(11,16)$.

\section{Verici Ameliyatındaki Cerrahi Teknik ve Organ Saklama Yöntemi}

Endokrin işlevinden yararlanmayı ön planda tutan pankreas aktarımında ekzokrin salgının durdurulması veya akaçlanması için üç farklı yönlendirme düşünülmüsstür : 1) pankreas kanalının bir polimerle doldurularak bloke edilmesi (Ancak greft rejeksiyonun ekzokrin salgıda amilaz monitorizasyonu ile anlașlabilmesine olanak sağlaması; bu yöntemin büyük çapta terkedilmesine neden olmuștur), 2) duodenum aracilığıyla mesaneye drenaj, 3) barsağa drenaj (11).

Günümüzde kadavradan sağlanan pankreas greftlerinin çoğu kendisiyle devamlı olan duodenum segmentiyle birlikte çoğul organ donörlerinden sağlanmaktadır. Genelde karaciğer, dalak ve duodenum'la birlikte (hepatopankreaticoduodenosplenektomi) çıkartılmaktadır (1, $5,14)$. Diğer bir yöntem ise önce karaciğerin sonra pankreasin vericiden peşisıra çıkartılmasıdır (3). Damar anomalilerinin varlığı önemli bir dezavantaj değildir. Teknik yönden pankreas organının çıkartılımı organ temini türleri arasında en güç olanıdır.

«Incisura jugularis»ten simfizis pubise kadar uzanan bir dikey kesiyle girişilir. Median sternotomi öncesi «lig. falciforme» bağlanıp kesilerek karaciğerin zarar görmemesine dikkat edilir. Karıniçi organlarının gözlenmesinden sonra nazogastrik sonda duodenum'a yerleştirilerek 250 - $500 \mathrm{ml}$ "povidone - iodine» veya $50 \mathrm{mg} / \mathrm{L}$ dozda «amphotericin" ile duodenum yıkanır. Karıniçi organları baş yönünde ekarte edilirken distal aorta ve "v. cava inferior"; donörün birden hemodinamik stabiliteyi kaybetmesi durumunda derhal perfüzyon yapmak için kullanılacak kateter yerleştirilimi amacıyla disseke edilir. Aorta'nın yeterli mobilizasyonu için «a. mesenterica inferior» bağlanıp kesilir. Aorta sol renal ven ve "a. mesenterica superior"a kadar meydana konulur. "Porta hepatis"de damariar ortaya konulur. Gastro-hepatik bağda aksesuvar veya yer değiştirmiş sol karaciğer arterinin var olup olmadığına dikkat edilir. "Porta hepatis»in arka bölümünde aksesu- 
var veya yer değiştirmiş sağ hepatik arterin varlığı da araştırılmalıdır. Koledok distalden bağlanıp kesildikten sonra, safra kesesi fundusuna yapılan küçük bir kesiyle biliyer dizgenin serum fizyolojikle yıkanması sağlanır. "A. hepatica communis» "truncus coeliacus»a kadar takip edilirek işaretlenir. "V. porta" hazırlanıp ve pankreas'ın 2 $\mathrm{cm}$ kadar karaciğer yönünde işaretlenir. Diyafragma kurusu açılarak supraçöliak aorta kontrol altına alınır. Mide, «omentum majus» kranial yönde ekarte edilirken pankreas tümüyle gözlenir ve ellenir. Dalakla birlikte hazırlanan pankreas kuyrugu retroperitoneal alandan ayrılarak medial yönde «a. mesenterica superior» «V. porta»ya döküldüğü yöreye kadar hazırlanır. "V. mesenterica inferior» bağlanıp kesilir. "A. gastrica sinistra" bağlanir. Duodenum ve pankreas başı Kocher manevrasiyla arka peritondan kurtarilır. "A. gastrica dextra" ve "a. gastroepiploica dextra" bağlanıp kesilir. "A. mesenterica superior" ve bifurkasyon proksimalinden aorta içine damar yıkamak ve prezervasyon çözeltisi vermek amacıyla kanüller yerleştirilir. Duodenum (6-8 cm'lik II. segmenti) içi, nazogastrikle ulaştırılan antiseptik çözeltiyle yeniden yıkandıktan sonra staplerle pilor ve 4 . kitasindan ayrilır. Donöre 20000 ünite i.v. heparin verilerek sistemik antikoagülasyon sağlanır. Aorta ve «v. cava inferior» distaline kateterler yerleştirilir. Çöliak aks proksimalinde aorta sıkıştırıldıktan sonra hızlı organ soğutulması en fazla 2,5 - 3 L kadar soğuk perfüzyon çözeltisiyle (tercihan University of Wisconsin çözeltisi : UW) aorta ve «a. mesenterica superior» dan retrograd yönde sağlanır. Bu süredeki venöz drenəj «V. cava inferior»a yerieștirilmiş kateter aracılığıyla bir torbaya veya toraks boşluğuna kanatılarak sağlanır. Bu sırada «V. porta»nın işaretlenmiş yerinden kateterle en fazla 1-1,5 L kadar perfüzyon sıvısı verilebilir. Böylelikle karaciğer, incebarsaklar, pankreas, duodenum, dalak ve her iki böbreğin perfüzyonu ve soğutulması sağlanmıș olur. "Arka masa" da pankreas'ın karaciğerden ayrılmasında «a. gastroduodenalis», «a. hepatica communis»ten çıktığı yerden bağlanıp kesilir, pankreas beslenmesinin «a. mesenterica superior» aracılığıyla bu arterden köken alan «a. pancreaticoduodenalis inierior» ile olması amaçlanır. "Truncus coeliacus" karaciğer tarafından bırakılırsa «a. lienalis» de bağlanarak kesilir ve bunun «a. mesenterica superior» ile uç - yan biçiminde veya yine vericiden alınmıs iliak arter greftinin bifurkasyonundan yararlanılarak anastomozu sağlanır. Portal ven de 
bir kısmı karaciğer tarafında kalmak üzere kesildiğinden gereken ven katkısı yine vericiden alınan «v. iliace» segmentiyle sağlanır (1, $5,12,14)$. Steril UW çözeltili torbalarda artı $4^{\circ} \mathrm{C}$ 'da saklanır. Dudenum segmenti hazırlanırken koledoktan yerleştirilen bir kanül aracılığıyla "ampulla Vateri"ye zarar verilmemesine dikkat edilir. Pankreas'in alt kenarındaki mezanterik yağ dokusu ve ə.beran damarlar emilmeyen dikiș materyali ile tek tek veya devamli olarak dikilir. «a. ve v. colica media", "a. gastroduodenalis» ve koledok ayrı ayrı olarak bağlanılır.

Eğer canlı akraba veya kadavradan sadece segmenter pankreas grefti alınacaksa; pankreas kuyruğundan portal ven hizasına kadar disseksiyon yapilır. Pankreas boynu ile "V. porta» arasindan parmak geçirilerek pankreas boynu başından ayrılır. Kadavra vericilerde bu işlemi kolaylaştırmak için koledok ve «3. gastroduodenalis» önceden bağlanir ve kesilir.

Genelde pankreatikoduodenal greftin soguk perfüzyonu için Ringerli laktad ve saklamak için ise UW (30 saat süreyle) veya (Euro Collins) EC (6 saat süreyle) çözeltisi kullanılmaktadır. Pankreas aktarımlarında öncü bir okul olan Minesoţ Üniversitesi'nde modifiye «hiperosmolar silica gel filtered plasma» (SGF) çözeltisi de saklama işlemi için uygulanılmıştır $(5,14)$.

\section{Alıcı Ameliyatinda Cerrahi Yöntem :}

Tek başına pankreas ve duodenum'un veya böbrekle birlikte olan aktarımlarmin ameliyat süresi 3-5 sa,at kadar sürmektedir. Endotrakeal anestezi sonrası venöz ve radial arter katèteri, nazogastrik sonda yerleştirilmiş, ameliyat masasındaki alıcıda idrar kateteri aracılığıyla mesane antibiyotikli çözeltilerle yıkanı. Cerrahi girişim sırasında kan şekeri ve volüm replasmanı yakından takip edilir. Kolloid çözeltiler, ozmolar diüretik ve dopamin gereğince kullanılmalıdır. İmmünosupresiv ve antibiyotikler (ve özellikle antifungal, antiviral ajanlar) ameliyat surasında ve sonrasında da verilir. Antitrombositik etki için heparinizasyon yerine salisilik asit veya dipiridamol kullanılır (13).

Pankreasin yerleştirilmesinde intraperitoneal gixișim yapılacaksa girişim şekli epigastrium'dan simfizis pubis'e kadar uzanan dikey bir kesiyledir. Daha sık kullanılan, ekstraperitoneal yaklaşımda; karın duvarı alt kesiminden yapilan suprainguinal, deri pililerine paralel kesiyle iliak damarlar hazırlanir. Uygun damar yapısı nedeniyle genel- 
de pankreas sağ iliak damarlara ağızlaştırılır. Eğer uğraşılan yöre dar ve damarlara ulaşımda güçlük çekiliyorsa; «a. ve v. iliaca interna» bağlanıp kesilerek «V. iliaca communis»in serbestleşmesi sağlanır. Önce verici pankreatikoduodenal greftinden çıkan «v. porta» ile alıcı «v. iliaca communis»i arasinda uç-yan anastomoz sağlanır. Sonra verici greftindeki «truncus coeliacus» veya, «a. lienalis» ve «a. mesenterica superior» arasında olușturulmuş anastomoz direkt olarak veya araya iliak damar grefti yerleştirilerek alıcı «a. iliaca externa»sı arasında ağılaştırma sağlanır. Pankreatikoduodenal greftin 6-8 cm. kadar tutan duodenal segmentindeki antimezenterik kenarından açılarak $5 \mathrm{~cm}$.'lik bir ağızla mesane kubbesinde mesane ile iki plan üzerinden anastomozu yapılır. Greft yanının drenajı için kesiyeri yanalından çıkmak üzere, yöreye çok delikli ve aktif emilime bağlanabilen bir dren yerleştirilir. Aslında pankreas ekzokrin salgısının barsağa drenajı en fizyolojik olanıdır. Ancak intra-abdominal enfeksiyon riskinin çok yüksek olması ve ekzokrin salgısının izlenmesiyle rejeksiyonun erken saptanması olanaklarından ycksun olması dezavantajlarıdır. İntraperitoneal yaklaşımla arka periton açlarak «v. cava inferior» aorta bifurkasyonu hizasında, distal 5 cm'i ve «a. iliaca communis» askıya alınır, üzerlerindeki lenfatiklerden temizlenir ve lenfatik ince damarlar bağlanır. Önce "v. porta" «v. cava inferior»a uç-yan, sonra «truncus coeliacus» veya iliak arterden oluşturulmuş arteriyel uzatma grefti uç-yan biçimde «a. iliaca communis» ile ağızlaştırılır. Önce venöz sonra arteriyel dizgedeki pensler açılır. Nihayet pankreasla birlikte olan dalak pankreas'a zarar vermeden çıkartılır. Pankreatikoduodenal greftin duodenal segmentinde $5 \mathrm{~cm}$ 'lik antimezenterik bir kesi sonrası, alıcı Treitz bağının $50 \mathrm{~cm}$ distalinde yan-yana iki plan üzerinden anastomoz sağlanır. Transplantasyon sonrası birkaç hafta pankreas ekzokrin salgısının kontrolu için "ampulla Vateri»den yerleștirilen bir pankreatik kanal kateteri (Fr 4 veya 6 ) barsak içinden geçirilebilir, proksimal yönde karŞı duvardan çıkartılıp 3-5 cm kadar tunelize edilerek kesiyeri yanalından deriye ulaştırılabilir. Karıniçindeki en derin çukura ayrı bir dren yerleştirilir.

Sonuçta; aktarım sonrası pankreasın bedendeki konumu, yapılan drenaj tipine ve anastomozlarına göre farklıdır (6,11) (Bakınız Şekil 1) . 
a

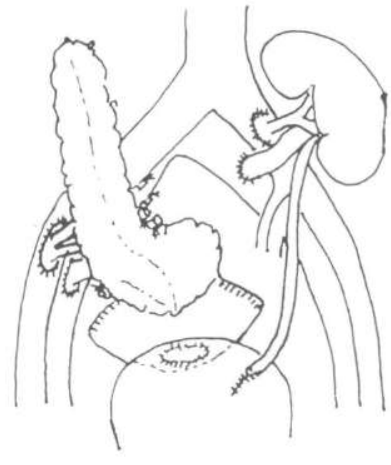

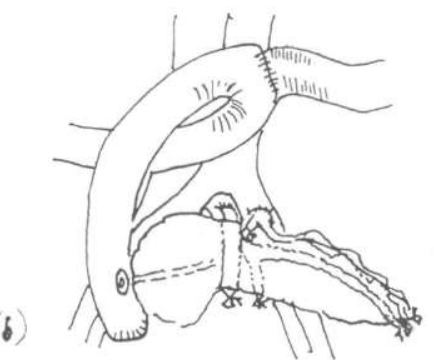

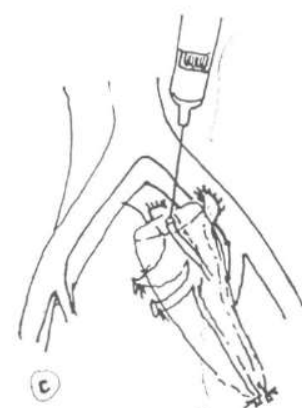

Șekil 1 : Pankreatikoduodenal ve segmenter grettin alıcıdaki

a) mesaneye ve b) barsağa yapılan drenaj türleri ve c) drenajsız ve ekzokrin kanala polimer enjeksiyonu yapılarak aktarımı

\section{Aktarım Sonrası İzleme}

Preoperatif başlanan antibiyotik proflaksisi ameliyat sonrası 2-5 gün daha devam edilir. Greft perfüzyonu, anatomisi ve sıvı birikimlerini araştırmayı gerektiren durumlarda ve postoperatif birinci günde karnın ultrasonografik ve radyonüklid sintigrafisi yapılır. Diürez sağlamak ve pankreas greftinde ödemi en azda tutmak için mannitol ve albumin desteği ameliyattan 24 - 48 saat sonrasına kadar sürdürülmelidir. Hastalar genelde 48-72 saatte ayağa kaldırılır ve 3.-5. günde ağızdan sıvı gıdalar almaya başlarlar. Mesane kateter drenajı postoperatif 7 gün süreyle yerinde tutularak çekilmeden önce düşük basınçlı bir sistografi veya radyoizotop taramayla duodeno-vezikal anastomoz bütünlüğü araştırılır 4,8,10,14). Greft vasküler trombozunun önüne geçmek için bir kaç gün intravenöz dekstran uygulanır. Aynı amaca yönelik olarak peşisıra haftalar veya aylarca düşük doz salisilik asit veya warfarin sodyum kullanılır (13). Doppler ultrasonografi ile damar açıklığı ve kan akımını izlemek, "real-time gray scale» ultrasonografi, sintigrafi, bilgisayarlı tomografi, MRI ile organ ve çevre dokularının değerlendirilmesini yapabilmek olanaklıdır $(11,14)$. Greftten venöz dönüs portal dizgeye ise çevrel kanda insulin düzeyi daha düşük olma- 
sına karşın kaval dizgeye olan venöz dönüşe göre kan şeker düzeylerinde pek farklılık görülmemektedir (11). Ekzojen insulin verilmesi serum glukozunun $200 \mathrm{mg} / \mathrm{dl}$ altında tutulmasını amaçlar. Glisemide ani çıkışlar veya sürekli yükselme koşullarında rejeksiyon, greft perfüzyonu yeterliliği araştırılmalıdır. Üriner dizge aracılığıyla fazla bikarbonat kaybı nedeniyle, hastaya kaybı kadar bikarbonat desteği verilmelidir.

Immünosupresyonda, dörtlü tedavi; yani CsA veya FK506, azothioperine, prednisone ve başlangıçta antitimosit globulin (ATG veya antilenfosit globulin : ALG) kullanılır. Akut rejeksiyon dönemleri methylprednisolone ve OKT3 ile kontrol altına alınmaya çalışılır. Aslında rejeksiyon tanısı konulduğunda önleyici önlemler almak için artık çok geç kalınmıştır $(2,13,15)$.

Monitorizasyonda kan şekeri, $\mathrm{Hb}_{1}$, serum amilazı rutindir. Serum C-peptid düzeyi greftin insulin oluşturduğunu belgeler. Ekzokrin salgı mesaneye drene edildiğinde idrar'da, kateter aracılığıyla barsağa drene edildiğinde de kateter kapsamındaki amilazı düzeyinden de bilgi edinilebilir. Greft yöresinde pankreas yanında yer alan drenden gelen sekresyonlardaki ve hasta serumundaki amilaz aktivitesinin yükselmesi anastomoz kaçağını gösterir. Normal işlevi bulunan greftlerde idrar amilaz değerleri bir saatlik idrar volümünde 10C0-8000 u/L'dir. Her hasta için saptanan bazal değerin \% 25'inden fazla bir sapma görülmesi halinde rejeksiyon düşünülmelidir. Pankreas enzimleriyle idrarda bikarbonat atılması nedeniyle idrar pH'sının normalde 7'nin üzerinde olması gerekirken asit tarafa kayması da atılım reaksiyonun erken belirtisi olarak kabul edilir. Hasta taburcu edildikten sonra önce haftada iki kez sonra uzayan aralıklarla poliklinik izlenmesine alınır. Açlık ve postprandial kan şekeri, C-peptid, $\mathrm{HbA}_{1}$, serum amilazı, idrar pH'sı, amilaz düzeyleri değerlendirilir. Her 3-6 ayda bir intravenöz ve oral glukoz tolerans testlrei, retinopati ve nöropati değerlendirilmeleri yapılır. Preüremik hastalarda düzenli aralıklarla serum kreatinin'i, azotemi ve kreatinin klirensi ölçülür $(11,14)$.

\section{Pankreas Aktarımı Sonrasında Komplikasyonlar}

Rejeksiyon, sıvı-elektrolit, asit-baz denge bozukluğu yanısıra; pankreatit, peripankreatik sıvı birikimleri, anastomoz kaçağı, fistül, peri ve intrapankreatik abseler, pankreas fibrozis'i, enfeksiyonları, sepsis ve greft damar trombozu akłarım sonrası komplikasyonlardan sayılabilir. Ayrica incebarsak ileusu ve kolesistit gibi laparatomi komplikasyonları da unutulmamalıdır. 
Pankreatit : Hiperamilazemiyle birlikte greft yöresinde hassasiyet ve ağrilar hemen her hastada transplantasyon sonrasında birkaç gün boyunca rastlanılur. Bu olay, organ aktarmmının pankreasa verdiği iskemik hasar ve organın ellenmesi nedeniyledir. Sağıltımında; ağızdan gıda alımı kesilir, intravenöz sıvı-elektrolit ve beslenme sağlanır. Önemli yöresel semptomlarda; laparatomi ile grefi yöresi drenaj1, nekrotik alanların debritmanı gerekebilir. Ancak pankreatit çok ön plana çıkmışsa; sepsisin önüne geçmek için greftin çıkartılması en emin çözümü sağlar.

Ekzokrin pankreas «terlemesi» : Pankreatit veya pankreas herhangi bir şekilde hasar gördüğü koşullarda transplantasyondan biriki gün sonra pankreas, kapsülünden amilaz ve diğer enzimlerden zengin bir sıvı çevreye salınır. Bu olay birkaç hafta sürebileceğinden greft yöresinde ameliyatta bir dren yerleştirilmiş olması olayın izlenmesini kolaylaştırır (11).

Anastomoz kaçakları ve fistülleri : Transplantasyon sonrası birinci ikinci haftada barsak veya mesane'ye olan anastomozlardan kaçak meydana gelmesi fistüle ve peripankreatik abseye de yol açar. Yöresel hassasiyet, ağrı yanısıra ateş ve lökositoz semptomatolojiyi oluşturur. Deriye fistülizasyonda enzimatik aktiviteyle ceri massere olarak derhal tanıya götürür. Abse oluşumu ise benzer semptomatolojide olan pankreatit ve rejeksiyonla karışabilir. Açıklanamayan karın ağrısı ve ateş erken laparatcmiyi; uygun anastomoz kaçağı kapatılmasını ve drenajı sağlayacaktır. Mesane anastomozundaki kaçak veya pankreas ekzokrin salgısının mesanede yaptığı yanglanmaların pankreas akaçlanmasının barsağa çevrilmesiyle (enferik konversiyon) düzeltil'ebilmesi de söz konusudur. Uzun süreli izlemelerde enterik konversiyonlar olguların \% 10-15'inde uygulanmıștır $(7,8,11,14)$.

Pankreas içi abseler : Organ aktarımından birkaç hafta sonra greft yöresinde ağrı, geçmeyen ateş ve gittikçe bozulan oranda kan şeker düzeyindeki kontrolun kaybı intrapankreatik abseleri belirler. Serum amilazı yükselmez. Olaydan subakut veya kronik ekzokrin sistem rejeksiyonu veya greftin sitomegalovirus enfeksiyonu sorumludur. Sağıltım ancak greftin çıkariılmasıyla olanaklıdır.

Greit damar trombozu : Groit kayplarmin \% 10-20'sinden sorumlu ve genelde aktarımdan sonrası ilk hafta, ha.tta daha sik olarak ilk 24 saat içinde greft damarlarındaki hemodinaminin zorlanmasına bağlanan, arteriyel veya venöz alanda ortaya çıkan bir olaydır. Ekzokrin pankreas kesiminin ödemli olduğu pankreatit damar trombo- 
zuna eğilim sağlar. Arteriyel trombozda birden kan şekeri yükselir ve amilaz düzeyi düşer. Birden ekzokrin salgı kesilir. Genelde ağrısızdır. Venöz tromioozda daha yavaş olarak kan şekeri ve genelde serum amilazı yükselir. Ekzckrin salgı yavaş yavaş azalarak kanlı hale dönüşür. Genelde greft alanında hassasiyet ve ağrı olur.

Erken tromboza uğrayan greftler çıkartılmalı, geç olanlar yöresel semptomlara yol açmiyorlarsa yerinde birakılmalıdırlar. Proflakside, antikoagülasyon, kanama komplikasyonuna yol açabileceğinden en az riskli olan dekstran ve saiisilik asit seçilmelidir. Bazen tromboz dişunda kanama, stenoz, psödoanevrizma veya arteriovenöz anevrizma oluşumları da söz konusu clabilir. Grefti trombiektomi ile kurtarma çabaları başarısızlıkla sonlanmıştır (11).

Metabolik sorunler : İdrar yollarma ekzokrin drenajla birlikte aşırı scdyum ve bikarbonat kayibi transplant alicılemnda dehidrasyon ve asidoz eğilimine yol açmaktadır. Hastalar genılde daha önce diyetlerinde yapılan kısıtlamalarden alıştıkları için bol sıvı içmekten korkarlar. Önemli böbrek fonksiyon bozukluğu ve așırı konstipasyonla sonuçlanabilir. Tuz içoren ve bikarbonat katılmış sıvıların alımı sağlttımda yeterlidir $(11,14)$.

Ekzokrin salgıdaki enzimlexin aktivasyonu : Mesanede kimyasal sistit, üretrit veya balanit’e yol açabilir. Sağıltımda rehidrasyon, idrarın alkalinizasyonu, üriner dizge analjezikleri ve birlikte enfeksiyon söz konusuysa antibiyotik kullanımı geçerlidir. Bazen enterik konversiyon gerekebilir (8).

Kesiyeri enfeksiyonları : Immünosupresyona bağlı olmayarak yüksek oranda bulunabilirler. En aza indirmek için median laparatomi ile pankreas'in intraperitoneal yerleştirilimi, pelvis'in aktif drenajı, somatostatin uygulanması, barsak dekontaminasyonu ve peri-operativ antibiyotik kullanilması tavsiye edilmektedir (14).

Rejeksiyon : En iyi rejeksiyon tedavisi meydana gelmesini önlemektir. Pankreas'in ekzokrin ve/veya endokrin salgi salgılayan ünitelerine yönelik olabilir. Genelde ekzokrin fonksiyon daha erken bozulur. Böbrekle birlikte aktarılan pankreas'da atılımı saptayabilmek zordur. Böbrek rejeksiyonu genelde pankr'eas rejeksiyonundan önce ortaya çıktığından, bu konuda yüksek şüphe oluşmasını sağlar. Diğer yandan pankreas'la biriikte aktarlan duodenal doku da pankreas'tan ayrı olarak atılım reaksiyonuna uğrayabilir. Bu konuaa sistoskopik (veya endoskopik) transcluodenal biopsi yardımci olabilir. Glisemi'nin giderek bozulması (dokunun \% 90'ı zarar gördüğünde) geç, C-peptid'in 
azalması endokrin işlevi yansıtma yönünden duyarlı̀ığına karşın güç olduğundan, seruma amilazının geçici yükselmesi atılım reaksiyonu açısından güvenilmezdir. Ekzokrin salgıda amilaz'ın azalması, monosit ve lenfoblastlarm belirmesi, serumda pankreas spesifik protein ve anodal tripsin varlığı, ateş ve greft yöresinde hassasiyet, anjiografisintigrafi-MRI-Doppler ultrasonografi'deki anormal buigular ve biopside lenfositik infiltrasyon ve endovaskülit tanı koydurucudur. En sık kullanılan yöntem ekzokrin salgıda amilaz düzeyinin ve sitolojinin izlenmesidir. Burada blast hücreler, eozinofiller ve nötrofillere oranla mononükleer hücreler, epitel hücreleri artar $(11,14)$.

Böbrek transplantasyonu sonrası yapılan tek başına pankreas aktarımlarında, değișik vericilerden organ aktarımı yapılanlarda; akut rejeksiyon ancak pankreas işlevinin yakından izlenmesiyle olanakl1dır. İnce iğne biopsisi ile histopatolojik tanı mesaneden sistoskop aracllığı ile sağlanabilir. Monoklonal (OKT3) veya poliklonal (ATGAM veya MALG) antikorlar ve steroid boluslarıyla; FK50€ veya CsA dozlarının yükseltilmesiyle rejeksiyon engellenmeye çalıșılır. Bu arada ilaçların kan düzeyleri, çevrel kandaki lökosit ve trombosit sayımlarıyla doz ve etkiler ayarlanmaya çalışılır. Steroidlerin periferik insulin direncini artırmaları, antikorların ve «azathioprine»in lökopeni, kemik iliği depresyonu, başta viral ve mantar olmak üzere enfeksiyonlara yatkınlı, Epstein-Barr virusu ile ilişkin lenfoma'ların veya Kaposi sarkomlarının ortaya çıkması gibi kötü yan tesirlerinden de korunmak gereklidir $(11,14,16)$.

\section{Sonuç}

Son evre böbrek yetmezliği ve diyabet tip I nedeniyle pankreas solid organ aktarımı, seçkin sağıltım yöntemi olarak kabul edilmektedir. Pankreas-böbrek aktarımı yapılan merkezlerde bir yıllık hasta ve pankreas grefti survi oranları ortalama \% 90 ve \% 70 olarak bildirilmektedir. Beş yıllık rakamlar ise $\% 70$ ve $\% 30$ olarak rapor edilmiştir $(2,7,9,10,13)$. Diyabet komplikasyonlarını engelleme veya erken tanı koyarak geri döndürme konusunda pankreas transplantının etkinliği için henüz yeterince uzun süre geçmemiştir. İzole pankreas transplantasyon endikasyonları diabet komplikasyonlarının çok erken evrede yakalanıldığı, hiperlabil ve insulin enjeksiyonları nedeniyle yaşam tarzının çok sıkıntılı olduğu, başka nedenlerle total pankreatektomi yapılan olgularla şimđililik sinırlanmıştır. Ancak diyabetin bu derece yaygınlığı dikkate alınırsa, belki de gelecekte en çok yapılacak organ aktarımı pankreas transplantasyonları olacaktır $(7,14)$. 
Pankreas damarlarında tromboz olayları da greft kaybının $\% 20$ 25 nedenidir (11).

\section{Pankreas Transplantasyonunun Geleceği}

Gelecekte daha iyi immünosupresyon veya donöre karşı daha etkin toleransın oluşturulması, rejeksiyon gibi komplikasyonların daha erken tanınmasına yönelik teknolojinin geliştirilmesi, zaten elde edilmiş olan oldukça iyi sonuçları daha da mükemmele yaklaştıracaktır.

\section{ÖZET}

"Diabetes mellitus tip I» hastalarda ve son evre böbrek hastalığı nedeniyle yapılan böbrek aktarımlarında pankreas'ın da birlikte transplantasyonu seçkin bir sağıitım yöntemi olarak giderek yaygın kabul görmektedir. Amaç, kan şcker düzeyini artık işlemeyen bir insulin salgılayıcı organın yerini alarak ayarlamak ve olabildiğince diyabet komplikasyonlarının önüne geçmek, stabil tutmak ve daha kaliteli bir yaşam tarzına ulassmakiıtır. Solid organin tam veya segmenter transplantasyonu \% 90 oranında bașarıya kadar ulaşmıştır. Korkulan komplikasyon olan; rejekssiyonu erken saptama ve sağıltımı için pankreas ekzokrin salgısını daha iyi akaçlanması ve daha iyi immünosupresyon yapılması için yeni stratejilerinin kurulması gerekmektedir.

Anahtar Kelimeler : Pankreas, Tip-I diyabet, Böbrek yetmezliği, Transplantasyon.

\section{SUMMARY}

Pancreatic Organ Transplantation

Consomitent transplantation of the pancreas with the kidney in type I diabetes mellitus patients and end-stage-renal disease has in time become a widely considered treatment of choice. The main purpose is to replace an insulin secreting organ which no longer works and hence to control blood glucose level, thus hinder the development of diabetic complications, or at least to stabilize it and perpetuate a better quality life style. Whole or segmental solid pancreatic organ transplantation has become successful with up to $90 \%$ survival. Establishing new strategies involving better immunosuppression and better drainage of the exocrine pancreas will enable the early detection and treatment of the dreaded complication of rejection.

Key Words : Pancreas, Type-I diabetes, Renal insufficiency, Transplantation. 


\section{KAYNAKLAR}

1. Bunzendahl H Ringe B Meyer $\mathrm{HJ}$ et al : Combination harvesting procedure for liver and whole pancreas. Transplant Int 1988; 1: 99-102.

2. Dawahra M Cloix P Martin X et al : Simultaneous transplantation of kidney and pancreas in diabetes patients. Transplantation Proceedings 1993; 25 : 2227 2229.

3. Delmonico FL Jenkiris RL Auchincloss $\mathrm{H}$ et al : Procurement of whole pancreas and liver from the same donor. Boston Center for Liver Transplantation, Boston, Massachusetts, U.S.A. 1985.

4. Eckhoff DE Ploeg RJ Wilson MA et al : Efficacy of $99 \mathrm{~m}$ Technetium voiding cystourethrogram for detection of duodenal leaks after pancreas transplantation. Transplantation Proceedings 199 (in press).

5. Gökçora IH : Karaciğer ve parkreas transplantasyonu için organ sağlamanın cerrahi yöntemi. Ank. Üniv. Tip Fak. Mec. 1993; 46 : 487-492.

6. Pirsch JD D'Alessandro AM Knechtle SJ et al : Simultaneous kidney-pancreas transplantation at the University of Wisconsin. Transplantation Proceedings 1993; 25 : 33-34.

7. Sollinger HW Pirsch JD D'Alessandro AM Kalayoğlu M et al : Advantages of bladder drainage in pancreas transplantation : A personal view. Clinical Transplants 1988, Sutherland and Moudry-Munns, pp : 32-36.

8. Sollinger HW Sasaki TM D'Alessandro AM et al : Indications for enteric conversion after pancreas transplantation with bladder drainage. Surgery 1992; 112 : 842-846.

9. Sollinger HW Ploeg RJ Eckhoff DE et al : Two hundred consecutive simultaneous pancreas-kidney transplants with bladder drainage. Surgery 1993; 114 : 736-744

10. Sollinger HW Messing EM Eckhoff DE et al : Urological complications in 210 consecutive simultaneous pancreas-kidney transplants with bladder drainage. Ann Surg 1993; 218 : 561-570.

11. Simmons RL Ildstad ST Smith CR et al : Transplantation in Principles of Surgery 6th Ed (Ed : Schwartz, Shires, Spencer) McGraw-Hill Inc, New York 1994 $\mathrm{pp}: 377-454$.

12. Starzl TE Todo S Tzakis A et al : Abdominal organ cluster transplantation for the treatment of upper abdominal malignancies. Ann Surg 1989; $210: 374-385$.

13. Stratta RJ Taylor RJ Zorn BH et al : Combined pancreas-kidney transplantation : Preliminary results and metabolic effects. Amer J Gastroenterol 1991; $86: 697-703$.

14. Stratta RJ Taylor RJ : Pancreatic transplantation. Chapter 28 in Digestive Tract Surgery : A Text and Atlas. Ed. Bell RH, Philadelphia, 1994.

15. Stratta RJ Taylor RJ Bynon JS et al : Surgical treatment of diabetes mellitus with pancreas transplantation. Ann Surg 1994; in press.

16. Sutherland DER Dunn DL Goetz FC et al : A 10-year experience with 290 pancreas transplants at a single institution. Ann Surg 1989; 210 : 274-285. 